\title{
Angiotensin-I-Converting Enzyme Inhibitory and Antioxidant Activities of Protein Hydrolysate from Muscle of Barbel (Barbus callensis)
}

\author{
Assaad Sila, ${ }^{1}$ Anissa Haddar, ${ }^{1}$ Oscar Martinez-Alvarez, ${ }^{2}$ and Ali Bougatef ${ }^{3}$ \\ ${ }^{1}$ Laboratory Enzyme and Bioconversion, National School of Engineering, PB 1173, 3038 Sfax, Tunisia \\ ${ }^{2}$ Institute of Food Science, Technology and Nutrition (ICTAN, CSIC), C/José Antonio Novais 10, 28040 Madrid, Spain \\ ${ }^{3}$ Higher Institute of Biotechnology of Sfax, PB 1175, 3038 Sfax, Tunisia
}

Correspondence should be addressed to Ali Bougatef; ali.bougatef79@gmail.com

Received 31 May 2013; Accepted 16 August 2013

Academic Editor: Souhail Besbes

Copyright (C) 2013 Assaad Sila et al. This is an open access article distributed under the Creative Commons Attribution License, which permits unrestricted use, distribution, and reproduction in any medium, provided the original work is properly cited.

\begin{abstract}
The present study investigated angiotensin-I-converting enzyme (ACE) inhibitory and antioxidant activities of barbel muscle protein hydrolysate prepared with Alcalase. The barbel muscle protein hydrolysate displayed a high ACE inhibitory activity $\left(\mathrm{CI}_{50}=0.92 \mathrm{mg} / \mathrm{mL}\right)$. The antioxidant activities of protein hydrolysate at different concentrations were evaluated using various in vitro antioxidant assays, including 1,1-diphenyl-2-picrylhydrazyl (DPPH) radical method and reducing power assay. The barbel muscle protein hydrolysate exhibited an important radical scavenging effect and reducing power. These results obtained by in vitro systems obviously established the antioxidant potency of barbel hydrolysate to donate electron or hydrogen atom to reduce the free radical. Furthermore, these bioactive substances can be exploited into functional foods or used as source of nutraceuticals.
\end{abstract}

\section{Introduction}

Hypertension is related to the incidence of coronary heart disease and its treatment is effective in reducing the risk of the disease [1]. The angiotensin-I-converting enzyme (EC 3.4.15.1; ACE) plays an important physiological role in the regulation of blood pressure [2]. The ACE can increase blood pressure by converting the inactive decapeptide angiotensin I to the potent vasoconstrictor angiotensin II. Therefore, inhibition of ACE activity is considered to be a useful therapeutic approach in the treatment of high blood pressure. Several effective oral ACE inhibitors have been developed, namely, captopril, enalapril, and lisinopril and all are currently used as clinical antihypertensive drugs [3]. Although synthetic ACE inhibitors are effective as antihypertensive drugs, they cause adverse side effects such as coughing, allergic reactions, and skin rashes. Therefore, research and development to find safer, innovative, and economical ACE inhibitors is necessary for the prevention and remedy of hypertension. Several reports have been published on the ACE inhibitory activity of peptides from food proteins, like casein [4], mushroom [5], whey protein [6], soybean [7], and fish proteins [8].

The excessive production of free radicals and the unbalanced mechanisms of antioxidant protection result in the onset of numerous chronic disorders: cancer, cardiovascular disease, diabetes, and other ageing-related diseases [9]. In the last decades, the use of synthetic antioxidants such as butylated hydroxyanisole (BHA) and butylated hydroxy-toluene (BHT) in stabilization of foods in agro-alimentary industry is suspected to have negative effects on consumer's health [10]. In recent years, hydrolysed proteins from many animal and plant sources such as milk casein [11], canola [12], and egg-yolk protein [13] have been found to possess antioxidant activity. In addition, aquatic products and by-products such as smooth hound protein [8], hoki frame protein [14], yellow stripe trevally [15], and shrimp carotenoprotein hydrolysate [16] have also proven to be good sources of antioxidant peptides. 
The new fisheries management constraint is how to adopt new development strategies coproducts. Currently, they are mostly converted into the meal and oil but it is a low valueadded processing. Improved economic performance for a better application of the coproducts is therefore necessary [17]. Enzymatic hydrolysis applied to marine products in order to produce bioactive peptides is one of the possible ways to effectively use these resources. This process allows recovery of proteins that retain their content of essential amino acids and peptides which may have biological functions.

Within this context, the present work was carried out aiming to study angiotensin-I-converting enzyme inhibitory and antioxidant activities of barbel muscle protein hydrolysate obtained by enzymatic treatments.

\section{Materials and Methods}

2.1. Reagents. Chemicals required for the assays including 1,1-diphenyl-2-picrylhydrazyl (DPPH), butylated hydroxyanisole (BHA), angiotensin-I-converting enzyme from rabbit lung, and the ACE synthetic substrate hippuryl-1-histidyll-leucine (HHL) were purchased from Sigma Chemical Co. (St. Louis, MO, USA). All other chemicals, namely, potassium ferricyanide, trichloroacetic acid (TCA), ferric chloride, sodium hydroxide, and other solvents, were of analytical grade.

2.2. Materials. The barbel (Barbus callensis) samples used in the present work were obtained from Barrage SIDI SAAD, Kairouan, Tunisia. The samples were packed in polyethylene bags, placed in ice (sample/ice ratio of about $1: 3(\mathrm{w} / \mathrm{w})$ ), and transported to the laboratory within $2 \mathrm{~h}$ after collection. The internal organs were separated and then stored in sealed plastic bags at $-20^{\circ} \mathrm{C}$.

2.3. Determination of Chemical Composition. The moisture and ash content were determined according to the AOAC standard methods as 930.15 and 942.05, respectively [18]. Total nitrogen content was determined by using the Dumas method. Samples were heated to $1050^{\circ} \mathrm{C}$ following AOAC 992.15 [18] in a LECO model FP-2000 protein/nitrogen analyser calibrated with EDTA. Crude fat was determined gravimetrically after Soxhlet extraction of dried samples with hexane. All measurements were performed in triplicate.

2.4. Preparation of Barbel Muscle Protein Hydrolysate $(B M P H)$. Barbel muscle $(500 \mathrm{~g})$, in $500 \mathrm{~mL}$ distilled water, was first minced using a grinder then cooked at $90^{\circ} \mathrm{C}$ for $20 \mathrm{~min}$ to inactivate endogenous enzymes. The cooked muscle sample was then homogenised in a Moulinex blender for about $20 \mathrm{~min}$. The samples were adjusted to $\mathrm{pH} 10.0$ and $50^{\circ} \mathrm{C}$. The substrate proteins were digested with Alcalase at a $3: 1$ enzyme/protein $(\mathrm{U} / \mathrm{mg}$ ) ratio for $5 \mathrm{~h}$. During the reaction, the $\mathrm{pH}$ of the mixture was maintained at the desired value by continuous addition of $\mathrm{NaOH}(4 \mathrm{~N})$ solutions. After the required digestion time, the reaction was stopped by heating the solutions for $20 \mathrm{~min}$ at $80^{\circ} \mathrm{C}$ to inactivate enzymes. Protein hydrolysate was then centrifuged at $5000 \times \mathrm{g}$ for
$20 \mathrm{~min}$ to separate soluble and insoluble fractions. Finally, the soluble fractions, referred to as protein hydrolysate, were freeze-dried using freeze-dryer at a temperature of $-50^{\circ} \mathrm{C}$ and a pressure of about $121 \mathrm{mbar}$ through a lyophilizer lab (CRIST, Alpha 1-2 LD plus, Germany) and then stored at $-20^{\circ} \mathrm{C}$ for further use.

2.5. Determination of the Degree of Hydrolysis. The degree of hydrolysis (DH), defined as the percent ratio of the number of peptide bonds cleaved $(h)$ to the total number of peptide bonds in the substrate studied $\left(h_{\text {tot }}\right)$, was calculated from the amount of base $(\mathrm{NaOH})$ added to keep the $\mathrm{pH}$ constant during the hydrolysis [19] according to the following equation:

$$
\mathrm{DH}(\%)=\frac{h}{h_{\mathrm{tot}}} \times 100=\frac{B \times \mathrm{Nb}}{\mathrm{MP}} \times \frac{1}{\alpha} \times \frac{1}{h_{\mathrm{tot}}} \times 100,
$$

where $B$ is the amount of $\mathrm{NaOH}$ consumed $(\mathrm{mL})$ to keep the $\mathrm{pH}$ constant during the proteolysis of the substrate. $\mathrm{Nb}$ is the normality of the base, MP is the mass $(\mathrm{g})$ of the protein $(\mathrm{N} \times$ 6.25), and $\alpha$ represents the average degree of dissociation of the $\alpha-\mathrm{NH}_{2}$ groups in the protein substrate expressed as

$$
\alpha=\frac{10^{\mathrm{pH}-\mathrm{pK}}}{1+10^{\mathrm{pH}-\mathrm{pK}}},
$$

where $\mathrm{pH}$ and $\mathrm{pK}$ are the values at which the proteolysis was conducted. The total number of peptide bonds $\left(h_{\text {tot }}\right)$ in the protein substrate was assumed to be $9.02 \mathrm{meq} / \mathrm{g}$.

2.6. Determination of Color. Sample was placed between two steel dishes with a hole of $5.7 \mathrm{~cm}$ diameter. The color of hydrolysates was determined with a tristimulus colorimeter (HunterLab D25 A-9, Hunter Associates Laboratory Inc., Reston, VA, USA) using the CIE Lab scale $\left(\mathrm{C} / 2^{\circ}\right)$, where $L^{*}, a^{*}$, and $b^{*}$ are the parameters that measure lightness, redness, and yellowness, respectively. A standard white plate with reflectance values of $L^{*}=93.68, a^{*}=-0.69$, and $b^{*}=-0.88$ was used as a reference. The results were the average of five measurements taken at ambient temperature at different points on the samples.

2.7. Amino Acid Analysis. Barbel muscle protein hydrolysate was dissolved $(1 \mathrm{mg} / \mathrm{mL})$ in ultrapure water and hydrolysed in constant boiling with $6 \mathrm{~N} \mathrm{HCl}$ containing $0.1 \%$ phenol and norleucine (Sigma-Aldrich, Inc., St. Louis, MO, USA) as internal standard. $\mathrm{HCl}$ was removed under vacuum after $24 \mathrm{~h}$ of hydrolysis $110^{\circ} \mathrm{C}$. Dried samples were reconstituted in application buffer and injected onto a Biochrom 20 amino acid analyser (Pharmacia, Barcelona, Spain).

2.8. Determination of ACE Inhibition Activity. ACEinhibitory activity was assayed as reported by Nakamura et al. [20]. A volume of $80 \mu \mathrm{L}$ containing different concentrations of test sample was added to $200 \mu \mathrm{L}$ of $5 \mathrm{mmol} / \mathrm{L} \mathrm{HHL}$ and preincubated at $37^{\circ} \mathrm{C}$ for $3 \mathrm{~min}$. Test sample and HHL were prepared in $100 \mathrm{mmol} / \mathrm{L}$ borate buffer ( $\mathrm{pH} 8.3$ ) containing $300 \mathrm{mmol} / \mathrm{L} \mathrm{NaCl}$. The reaction was then initiated by adding 
$20 \mu \mathrm{L}$ of $0.1 \mathrm{U} / \mathrm{mL}$ ACE from rabbit lung prepared in the same buffer. After incubation at $37^{\circ} \mathrm{C}$ for $30 \mathrm{~min}$ the enzymatic reaction was stopped by adding $250 \mu \mathrm{L}$ of $0.05 \mathrm{~mol} / \mathrm{L} \mathrm{HCl}$. The liberated hippuric acid (HA) was extracted with ethyl acetate $(1.7 \mathrm{~mL})$ and then evaporated at $95^{\circ} \mathrm{C}$ for $10 \mathrm{~min}$. The residue was dissolved in $1 \mathrm{~mL}$ of distilled water and the absorbance of the extract at $228 \mathrm{~nm}$ was determined using a UV-visible spectrophotometer. ACE-inhibitory activity was calculated using the equation

$$
\text { ACE inhibition }(\%)=\left[\frac{B-A}{B-C}\right] \times 100,
$$

where $A$ is the absorbance of HA generated in the presence of ACE inhibitor component, $B$ is the absorbance of HA generated without ACE inhibitors, and $C$ is the absorbance of HA generated without ACE (corresponding to HHL autolysis in the course of enzymatic assay). The $\mathrm{IC}_{50}$ value was defined as the concentration of inhibitor required to reduce the hippuric acid peak by $50 \%$ (indicating $50 \%$ inhibition of ACE). Method of Bradford [21] using bovine serum albumin as a standard was used.

\subsection{Antioxidant Activity}

2.9.1. DPPH Free Radical-Scavenging Activity. The DPPH free radical-scavenging activity of barbel muscle protein hydrolysate was determined as described by Bersuder et al. [22]. A volume of $500 \mu \mathrm{L}$ of each sample at different concentrations ( 1 to $5 \mathrm{mg} / \mathrm{mL}$ ) was added to $375 \mu \mathrm{L}$ of $99 \%$ ethanol and $125 \mu \mathrm{L}$ of DPPH solution $(0.02 \%$ in ethanol) as free radical source. The mixtures were shaken then incubated for $60 \mathrm{~min}$ in darkness at room temperature. Scavenging capacity was measured spectrophotometrically by monitoring the decrease in absorbance at $517 \mathrm{~nm}$. In its radical form, DPPH has an absorption band at $517 \mathrm{~nm}$ which disappears upon reduction by an antiradical compound. Lower absorbance of the reaction mixture indicated higher DPPH free radicalscavenging activity. BHA was used as positive control. DPPH radical-scavenging activity was calculated as follows:

DPPH radical-scavenging activity (\%)

$$
=\frac{A_{\text {control }}-A_{\text {sample }}}{A_{\text {control }}} \times 100,
$$

where $A_{\text {control }}$ is the absorbance of the control reaction (containing all reagents except the sample) and $A_{\text {sample }}$ is the absorbance of test sample (with the DPPH solution). The experiment was carried out in duplicate and the results are mean values.

2.9.2. Reducing Power Assay. The ability of BMPH to reduce iron(III) was determined according to the method of Yildirim et al. [23]. An aliquot of $1 \mathrm{~mL}$ sample of barbel hydrolysate at different concentrations ( 1 to $5 \mathrm{mg} / \mathrm{mL}$ ) was mixed with $2.5 \mathrm{~mL}$ of $0.2 \mathrm{M}$ phosphate buffer ( $\mathrm{pH} 6.6$ ) and $2.5 \mathrm{~mL}$ of $1 \%(\mathrm{w} / \mathrm{v})$ potassium ferricyanide solution. The mixtures were incubated for $30 \mathrm{~min}$ at $50^{\circ} \mathrm{C}$. After incubation, $2.5 \mathrm{~mL}$ of
$10 \%(\mathrm{w} / \mathrm{v})$ TCA was added and the reaction mixtures were then centrifuged for $10 \mathrm{~min}$ at $10000 \mathrm{rpm}$. Finally, $2.5 \mathrm{~mL}$ of the supernatant solution from each sample mixture was mixed with $2.5 \mathrm{~mL}$ of distilled water and $0.5 \mathrm{~mL}$ of $0.1 \%(\mathrm{w} / \mathrm{v})$ ferric chloride. After a $10 \mathrm{~min}$ reaction time, the absorbance of the resulting solutions was measured at $700 \mathrm{~nm}$. Higher absorbance of the reaction mixture indicated higher reducing power. The control was conducted in the same manner, except that distilled water was used instead of sample. Values presented are the mean of triplicate analyses. BHA was used as reference antioxidant.

2.10. Statistical Analyses. Statistical analyses were performed with Stratgraphics ver. 5.1, professional edition (Manugistics Corp., USA) using ANOVA analysis. Differences were considered significant at $P<0.05$. All tests were carried out in triplicate.

\section{Results and Discussion}

3.1. Production of Barbel Muscle Protein Hydrolysate. It has been demonstrated that the biological activities of proteins can be increased through hydrolysis with certain enzymes [24]. Furthermore, the biological activity of protein hydrolysates depends on the protein substrate, the specificity of the enzyme, the conditions used during proteolysis, and the degree of hydrolysis. Since enzymes have specific cleavage positions on polypeptides chain, protein hydrolysates were prepared from barbell muscle by treatment with Alcalase to obtain peptides with different amino acids sequences and peptides length.

\subsection{Chemical Composition of Barbel Muscle Protein} Hydrolysate. The chemical composition of barbel muscle protein hydrolysate was determined. As shown in Table 1, the protein hydrolysate had high protein content $(84.82 \%)$ and could be an essential source of proteins. The high protein content was a result of the solubilisation of proteins during hydrolysis, the removal of insoluble undigested nonprotein substances, and the partial removal of lipid after hydrolysis [25]. Barbel protein hydrolysate had relatively low lipid content $(2.56 \%)$. Similar lipid levels (3.1\%) were reported by Balti et al. [26] in the protein hydrolysate prepared from cuttlefish (Sepia officinalis) by-products. The ash content was $11.08 \%$. These results are similar to those found in protein hydrolysate prepared from sardinella muscle (between $10 \%$ and $11.7 \%$ ) [27].

3.3. Determination of Color. Color influences the overall acceptability of food products. The color values of the BMPH are also shown in Table 1. Indeed, barbel muscle protein hydrolysate was dark $\left(L^{*}=88.18\right)$ and yellow $\left(b^{*}=\right.$ 15.58). Enzymatic browning reactions are assumed to have contributed to the reduction in the luminosity. Sathivel et al. [28] reported that the color of whole herring and herring byproduct hydrolysates, prepared using Alcalase, varied with substrates. Herring gonad hydrolysate was the darkest $\left(L^{*}=\right.$ 74.6) and most yellowish $\left(b^{*}=18\right)$, whereas whole herring 
TABlE 1: Proximate composition of barbel muscle protein hydrolysate.

\begin{tabular}{lc}
\hline Composition & BMPH \\
\hline Protein (\%) & $84.82 \pm 7.4$ \\
Fat (\%) & $2.56 \pm 0.12$ \\
Ash (\%) & $8.87 \pm 0.20$ \\
Moisture (\%) & $11.08 \pm 0.07$ \\
Color & \\
$L^{*}$ & $88.18 \pm 0.06$ \\
$a^{*}$ & $0.07 \pm 0.01$ \\
$b^{*}$ & $15.58 \pm 0.09$ \\
\hline
\end{tabular}

Physicochemical composition was calculated based on the dry mater.

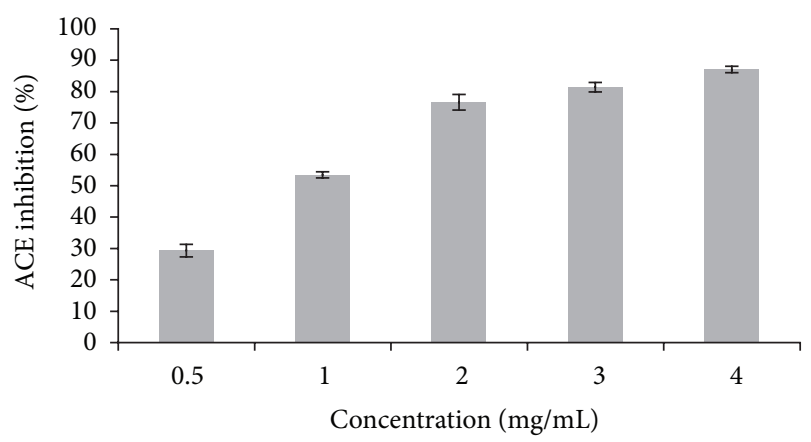

FIGURE 1: ACE-inhibitory activity of barbel muscle protein hydrolysate at different concentrations.

hydrolysate was the lightest $\left(L^{*}=89.4\right)$ and least yellowish $\left(b^{*}=8.0\right)$.

3.4. Amino Acid Composition. The amino acid composition of BMPH expressed as residues per 1000 total amino acid residues is shown in Table 2. Alanine is the most dominant amino acid in the barbel muscle hydrolysate (94 residues per 1000 residues). The BMPH has a high percentage of essential amino acids such as histidine, isoleucine, leucine, lysine, valine, and methionine $(23,40,80,86,47$, and 29 residues per 1000 residues, resp.). From the results, BMPH shows a high nutritional value, based on its amino acid profile, and could be a good dietary protein supplement.

Furthermore, amino acid composition analyses of BMPH help to study their biological effect and mechanism. Amino acids in the hydrolysate are possibly involved in antioxidative activity. Several amino acids, such as Tyr, Met, His, Lys, and Trp, may significantly contribute to the antioxidant activity of the hydrolysates [29].

3.5. ACE Inhibitory Activity of BMPH. The hydrolysate obtained with Alcalase was then assayed for ACE inhibitory activity. Result showed that the ACE inhibitory activities increase with the increase of hydrolysate concentration (Figure 1). Furthermore, the highest ACE inhibitory activity $87 \%$ was observed at a concentration of $4 \mathrm{mg} / \mathrm{mL}$.

The $\mathrm{IC}_{50}$ values for ACE inhibition of BMPH was $0.92 \mathrm{mg} / \mathrm{mL}$ (Figure 1). The $\mathrm{IC}_{50}$ value of $\mathrm{BMPH}$ was lower
TABLE 2: Amino acid composition of barbel muscle protein hydrolysate (BMPH).

\begin{tabular}{lc}
\hline Amino acids & $\begin{array}{c}\text { Number of residues/1000 } \\
\text { BMPH }\end{array}$ \\
\hline Asx (D + N) & 104 \\
Thr (T) & 51 \\
Ser (S) & 58 \\
Glx (E + Q) & 154 \\
Gly (G) & 83 \\
Ala (A) & 94 \\
Cys (C) & 4 \\
Val (V) & 47 \\
Met (M) & 29 \\
Ile (I) & 40 \\
Leu (L) & 80 \\
Tyr (Y) & 21 \\
Phe (F) & 30 \\
OHLys & 1 \\
His (H) & 23 \\
Lys (K) & 86 \\
Arg (R) & 46 \\
Pro (P) & 41 \\
OHPro & 8 \\
TEAA & 407 \\
\hline Asx Asp &
\end{tabular}

Asx $=$ Asp + Asn; Glx $=$ Glu + Gln

TEAA: total essential amino acids.

than those of hydrolysates from oyster, scallop, codfish skin, and herring skin which presented an $\mathrm{IC}_{50}$ greater than $10 \mathrm{mg} / \mathrm{mL}$ [30], whereas it is higher than those from sardine $\left(\mathrm{IC}_{50}=0.62 \mathrm{mg} / \mathrm{mL}\right)[31]$ and sardine $\left(\mathrm{IC}_{50}=0.082 \mathrm{mg} / \mathrm{mL}\right)$ [32]. Proteolysis can operate either sequentially, releasing one peptide at a time, or through the formation of intermediates that are further hydrolyzed to smaller peptides as proteolysis progresses, which is often termed "the zipper mechanisms" [33].

\subsection{Antioxidant Activity of $B M P H$}

3.6.1. DPPH Radical-Scavenging Capacity. DPPH is a stable free radical which can be reduced by a proton-donating substrate such as an antioxidant, causing the decolorization of the DPPH and reducing the absorbance at $514 \mathrm{~nm}$. The rate of the decrease in the color gives us an idea about the DPPH scavenging capacity.

DPPH radical scavenging capacities of BMPH and BHA (used as positive control) are shown in Figure 2(a). BMPH was a strong radical scavenger with an $\mathrm{IC}_{50}$ of $1.12 \mathrm{mg} / \mathrm{mL}$. Similar results were reported by Guerard et al. [34] when they studied the free radical-scavenging activity in the hydrolysis of shrimp processing discards. BMPH showed a DPPH free radical-scavenging activity in the range of the concentrations tested. This activity was significantly lower than that of BHA at the same concentration. 


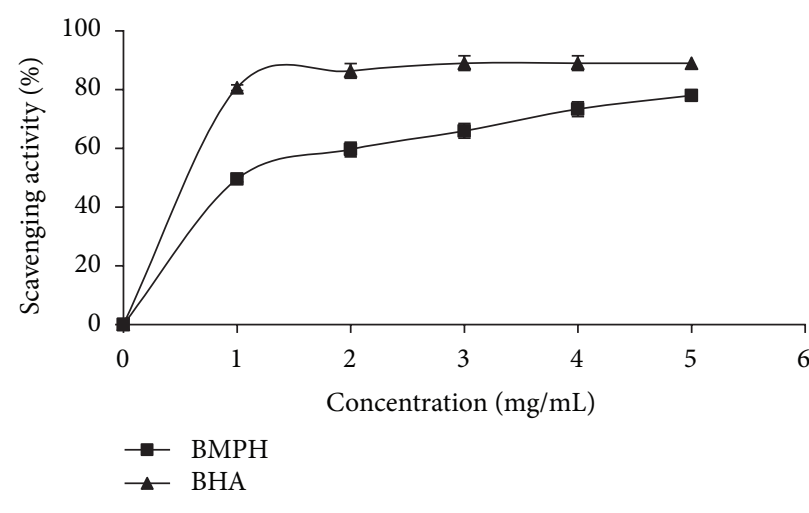

(a)

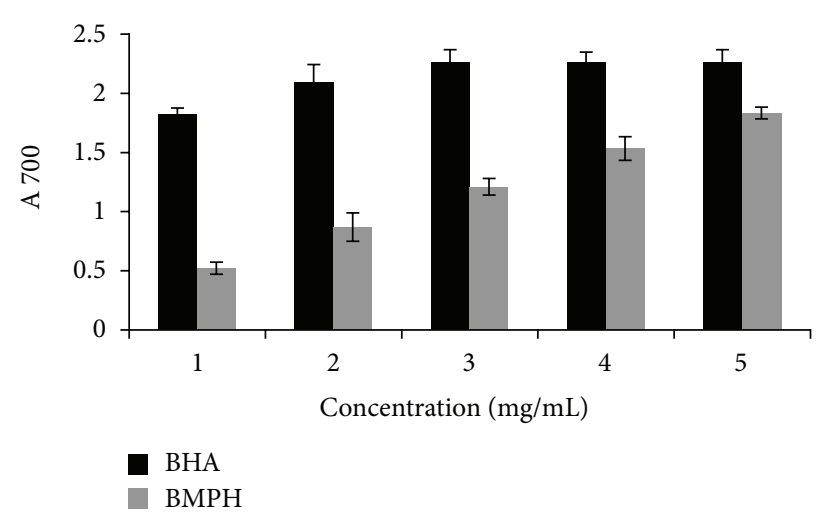

(b)

FIGURE 2: Antioxidant activities of barbel muscle protein hydrolysate at different concentrations. (a) DPPH free radical-scavenging activities, (b) reducing power.

3.6.2. Reducing Power. The reducing power assay is often used to evaluate the ability of an antioxidant to donate an electron or hydrogen. Many reports have revealed that there is a direct correlation between antioxidant activities and reducing power of certain bioactive compounds [35]. In this assay, the ability of $\mathrm{BMPH}$ to reduce $\mathrm{Fe}^{3+}$ to $\mathrm{Fe}^{2+}$ was determined.

The presence of antioxidants in the protein hydrolysate results in reduction of the $\mathrm{Fe}^{3+} /$ ferric cyanide complex to the ferrous form. Therefore, the $\mathrm{Fe}^{2+}$ complex can be monitored by measuring the formation of Perl's Prussian blue at $700 \mathrm{~nm}$. Figure 2(b) shows the reducing power (as indicated by the absorbance at $700 \mathrm{~nm}$ ) of BMPH at different concentrations compared with that of BHA as the standard. BMPH showed some degree of electron donation capacity. At 4 and $5 \mathrm{mg} / \mathrm{mL}$, the reducing power of $\mathrm{BMPH}$ was 1.532 and 1.833 , respectively.

\section{Conclusion}

Fish protein hydrolysates in general are considered safe products and they are not subjected to restricted use in foods. Therefore, barbel muscle protein hydrolysate can be used in food systems such as meat products as a natural additive possessing antioxidative properties. Further works should be done to isolate and identify some specific peptides in barbel protein hydrolysate which are responsible for the overall biological activity.

\section{Acknowledgment}

This work was funded by the Ministry of Higher Education and Scientific Research, Tunisia.

\section{References}

[1] S. MacMahon, R. Peto, J. Cutler et al., "Blood pressure, stroke, and coronary heart disease. Part 1, prolonged differences in blood pressure: prospective observational studies corrected for the regression dilution bias," The Lancet, vol. 335, no. 8692, pp. 765-774, 1990.

[2] L. T. Skeggs Jr., J. R. Kahn, and N. P. Shumway, "The preparation and function of the hypertensin-converting enzyme," The Journal of Experimental Medicine, vol. 103, no. 3, pp. 295-299, 1956.

[3] D. J. Kuster and G. R. Marshall, "Validated ligand mapping of ACE active site," Journal of Computer-Aided Molecular Design, vol. 19, no. 8, pp. 609-615, 2005.

[4] S. V. Silva and F. X. Malcata, "Caseins as source of bioactive peptides," International Dairy Journal, vol. 15, no. 1, pp. 1-15, 2005.

[5] D. H. Lee, J. H. Kim, J. S. Park, Y. J. Choi, and J. S. Lee, "Isolation and characterization of a novel angiotensin I-converting enzyme inhibitory peptide derived from the edible mushroom Tricholoma giganteum," Peptides, vol. 25, no. 4, pp. 621-627, 2004.

[6] V. Vermeirssen, A. van der Bent, J. van Camp, A. van Amerongen, and W. Verstraete, "A quantitative in silico analysis calculates the angiotensin I converting enzyme (ACE) inhibitory activity in pea and whey protein digests," Biochimie, vol. 86, no. 3, pp. 231-239, 2004.

[7] M. Kuba, C. Tana, S. Tawata, and M. Yasuda, "Production of angiotensin I-converting enzyme inhibitory peptides from soybean protein with Monascus purpureus acid proteinase," Process Biochemistry, vol. 40, no. 6, pp. 2191-2196, 2005.

[8] A. Bougatef, N. Nedjar-Arroume, R. Ravallec-Plé et al., "Angiotensin I-converting enzyme (ACE) inhibitory activities of sardinelle (Sardinella aurita) by-products protein hydrolysates obtained by treatment with microbial and visceral fish serine proteases," Food Chemistry, vol. 111, no. 2, pp. 350$356,2008$.

[9] P. M. Kris-Etherton, K. D. Hecker, A. Bonanome et al., "Bioactive compounds in foods: their role in the prevention of cardiovascular disease and cancer," American Journal of Medicine, vol. 113, no. 9, pp. 71S-88S, 2002.

[10] M. Namiki, "Antioxidants/antimutagens in food," Critical Reviews in Food Science and Nutrition, vol. 29, no. 4, pp. 273300, 1990.

[11] B. Hernández-Ledesma, A. Quirós, L. Amigo, and I. Recio, "Identification of bioactive peptides after digestion of human 
milk and infant formula with pepsin and pancreatin," International Dairy Journal, vol. 17, no. 1, pp. 42-49, 2007.

[12] N. Cumby, Y. Zhong, M. Naczk, and F. Shahidi, "Antioxidant activity and water-holding capacity of canola protein hydrolysates," Food Chemistry, vol. 109, no. 1, pp. 144-148, 2008.

[13] S. Sakanaka, Y. Tachibana, N. Ishihara, and L. R. Juneja, "Antioxidant activity of egg-yolk protein hydrolysates in a linoleic acid oxidation system," Food Chemistry, vol. 86, no. 1, pp. 99-103, 2004.

[14] S.-Y. Kim, J.-Y. Je, and S.-K. Kim, "Purification and characterization of antioxidant peptide from hoki (Johnius belengerii) frame protein by gastrointestinal digestion," Journal of Nutritional Biochemistry, vol. 18, no. 1, pp. 31-38, 2007.

[15] V. Klompong, S. Benjakul, D. Kantachote, and F. Shahidi, "Antioxidative activity and functional properties of protein hydrolysate of yellow stripe trevally (Selaroides leptolepis) as influenced by the degree of hydrolysis and enzyme type," Food Chemistry, vol. 102, no. 4, pp. 1317-1327, 2007.

[16] A. Sila, N. Sayari, R. Balti, O. Martinez-Alvarez, N. Nedjararroume, and A. Bougatef, "Biochemical and antioxidant properties of peptidic fraction of carotenoproteins generated from shrimp by-products by enzymatic hydrolysis," Food Chemistry, 2013.

[17] OFIMER, "Synthèse de l'Etude, 'La filière française des coproduits de la pêche et de l'aquaculture: état des lieux et analyse"' OFIMER, Paris, Farnce, 2004.

[18] AOAC, Official Methods of Analysis, Association of Official Analytical, 17th edition, 2000.

[19] J. Adler-Nissen, "A review of food hydrolysis specific areas," in Enzymic Hydrolysis of Food Proteins, J. Adler-Nissen, Ed., pp. 57-109, Elsevier, Copenhagen, Denmark, 1986.

[20] Y. Nakamura, N. Yamamoto, K. Sakai, A. Okubo, S. Yamazaki, and T. Takano, "Purification and characterization of angiotensin I-converting enzyme inhibitors from sour milk," Journal of Dairy Science, vol. 78, no. 4, pp. 777-783, 1995.

[21] M. M. Bradford, "A rapid and sensitive method for the quantitation of microgram quantities of protein utilizing the principle of protein dye binding," Analytical Biochemistry, vol. 72, no. 1-2, pp. 248-254, 1976.

[22] P. Bersuder, M. Hole, and G. Smith, "Antioxidants from a heated histidine-glucose model system. I: investigation of the antioxidant role of histidine and isolation of antioxidants by high-performance liquid chromatography," Journal of the American Oil Chemists' Society, vol. 75, no. 2, pp. 181-187, 1998.

[23] A. Yildirim, A. Mavi, and A. A. Kara, "Determination of antioxidant and antimicrobial activities of Rumex crispus L. extracts," Journal of Agricultural and Food Chemistry, vol. 49, no. 8, pp. 4083-4089, 2001.

[24] H.-M. Chen, K. Muramoto, and F. Yamauchi, "Structural analysis of antioxidative peptides from soybean $\beta$-conglycinin," Journal of Agricultural and Food Chemistry, vol. 43, no. 3, pp. 574-578, 1995.

[25] S. Benjakul and M. T. Morrissey, "Protein hydrolysates from pacific whiting solid wastes," Journal of Agricultural and Food Chemistry, vol. 45, no. 9, pp. 3423-3430, 1997.

[26] R. Balti, A. Bougatef, N. E.-H. Ali, D. Zekri, A. Barkia, and M. Nasri, "Influence of degree of hydrolysis on functional properties and angiotensin I-converting enzyme-inhibitory activity of protein hydrolysates from cuttlefish (Sepia officinalis) byproducts," Journal of the Science of Food and Agriculture, vol. 90, no. 12, pp. 2006-2014, 2010.
[27] H. Ben Khaled, N. Ktari, O. Ghorbel-Bellaaj, M. Jridi, I. Lassoued, and M. Nasri, "Composition, functional properties and in vitro antioxidant activity of protein hydrolysates prepared from sardinelle (Sardinella aurita) muscle," Journal of Food Science and Technology, vol. 45, pp. 165-169, 2011.

[28] S. Sathivel, P. J. Bechtel, J. Babbitt et al., "Biochemical and functional properties of herring (Clupea harengus) byproduct hydrolysates," Journal of Food Science, vol. 68, no. 7, pp. 21962200, 2003.

[29] H.-M. Chen, K. Muramoto, F. Yamauchi, K. Fujimoto, and K. Nokihara, "Antioxidative properties of histidine-containing peptides designed from peptide fragments found in the digests of a soybean protein," Journal of Agricultural and Food Chemistry, vol. 46, no. 1, pp. 49-53, 1998.

[30] H.-L. He, X.-L. Chen, H. Wu, C.-Y. Sun, Y.-Z. Zhang, and B.-C. Zhou, "High throughput and rapid screening of marine protein hydrolysates enriched in peptides with angiotensinI-converting enzyme inhibitory activity by capillary electrophoresis," Bioresource Technology, vol. 98, no. 18, pp. 34993505, 2007.

[31] K. Yokoyama, H. Chiba, and M. Yoshikawa, "Peptide inhibitors for angiotensin I-converting enzyme from thermolysin digest of dried bonito," Bioscience, Biotechnology, and Biochemistry, vol. 56, no. 10, pp. 1541-1545, 1992.

[32] H. Matsufuji, T. Matsui, E. Seki, K. Osajima, M. Nakashima, and Y. Osajima, "Angiotensin I-converting enzyme inhibitory peptides in an alkaline protease hydrolyzate derived from sardine muscle," Bioscience, Biotechnology, and Biochemistry, vol. 58, no. 12, pp. 2244-2245, 1994.

[33] D. Panyam, A. Kilara, and W. A. M. Mutilangi, "Functional properties of hydrolysates from proteolysis of heat-denatured whey protein isolate," Journal of Food Science, vol. 61, no. 2, pp. 270-303, 1996.

[34] F. Guerard, M. T. Sumaya-Martinez, D. Laroque, A. Chabeaud, and L. Dufossé, "Optimization of free radical scavenging activity by response surface methodology in the hydrolysis of shrimp processing discards," Process Biochemistry, vol. 42, no. 11, pp. 1486-1491, 2007.

[35] J. Synowiecki and N. A. A. Q. Al-Khateeb, "The recovery of protein hydrolysate during enzymatic isolation of chitin from shrimp Crangon crangon processing discards," Food Chemistry, vol. 68, no. 2, pp. 147-152, 2000. 

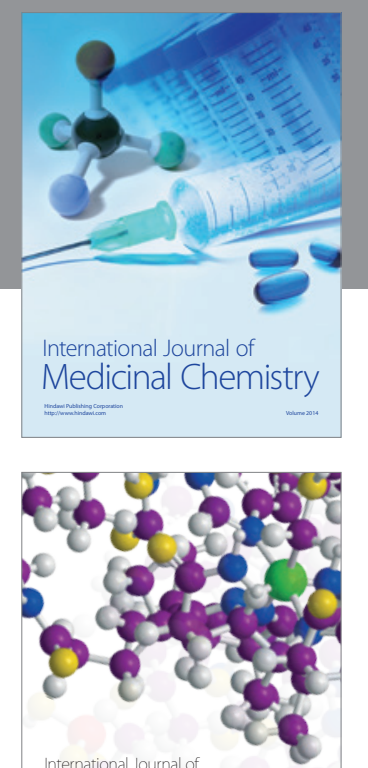

\section{Carbohydrate} Chemistry

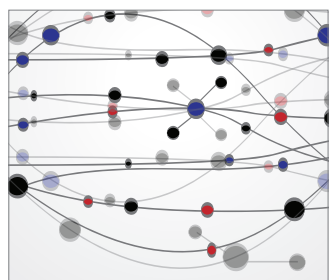

The Scientific World Journal
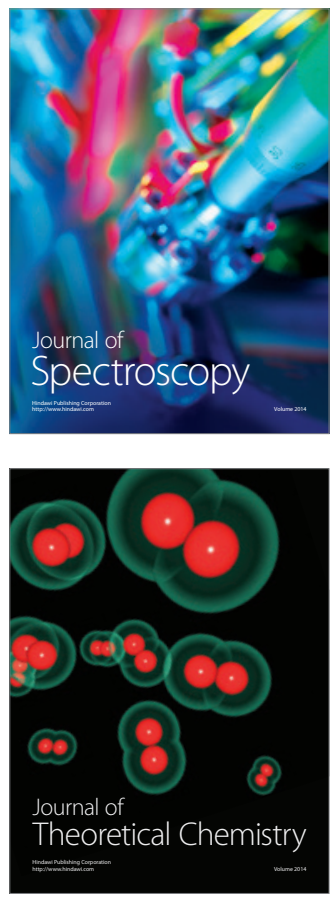
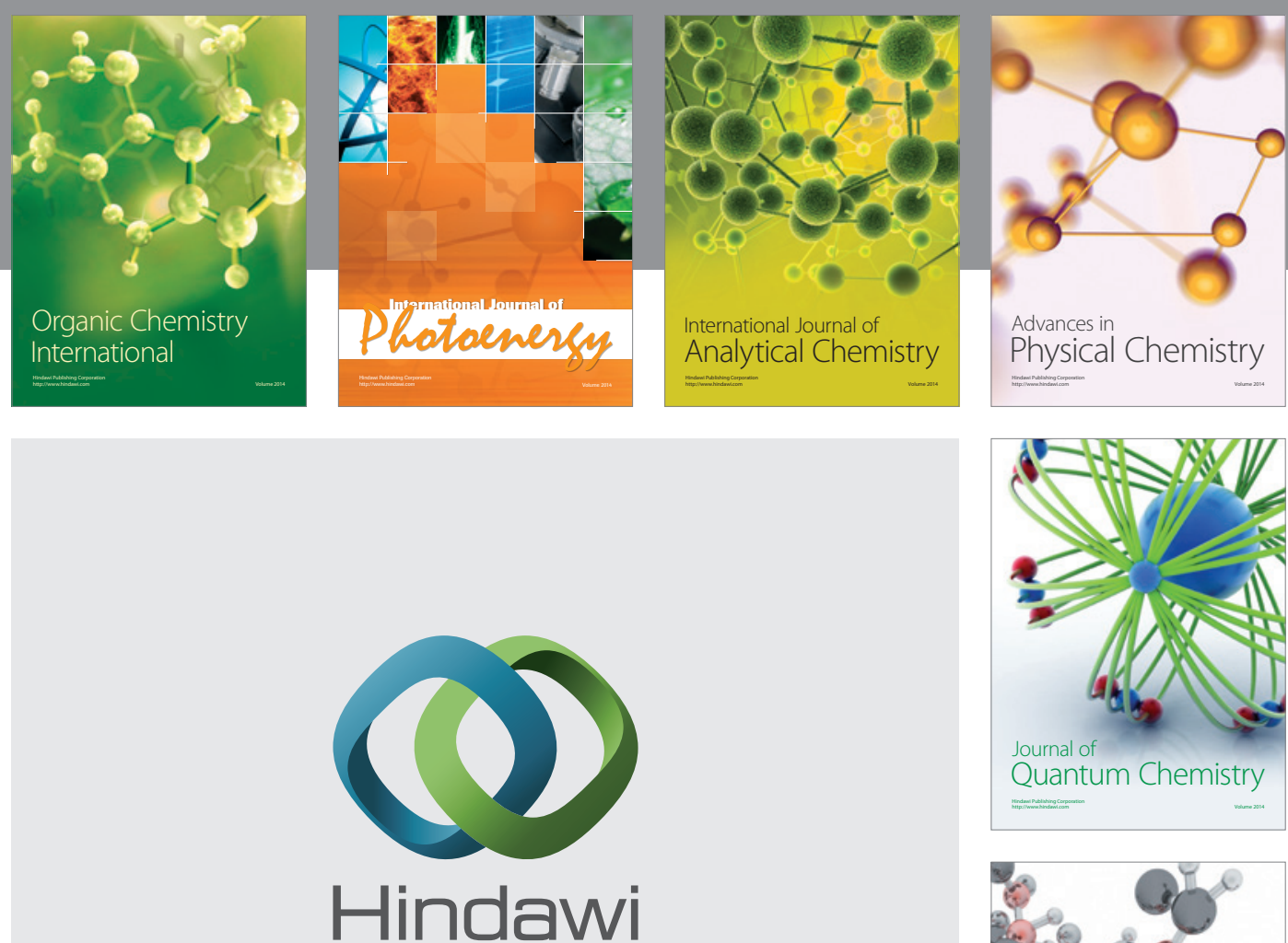

Submit your manuscripts at

http://www.hindawi.com

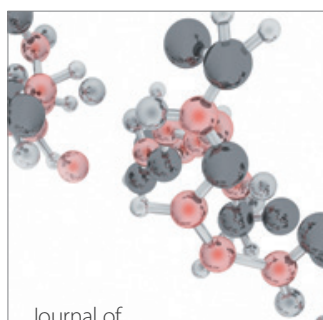

Analytical Methods

in Chemistry

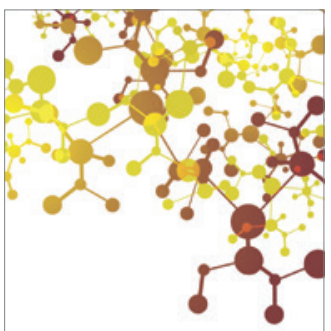

Journal of

Applied Chemistry

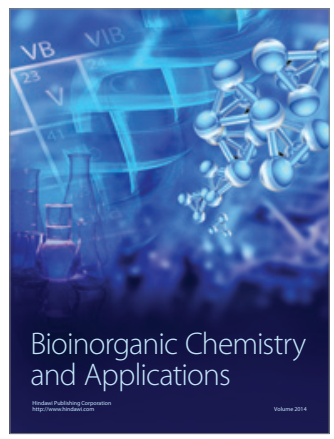

Inorganic Chemistry
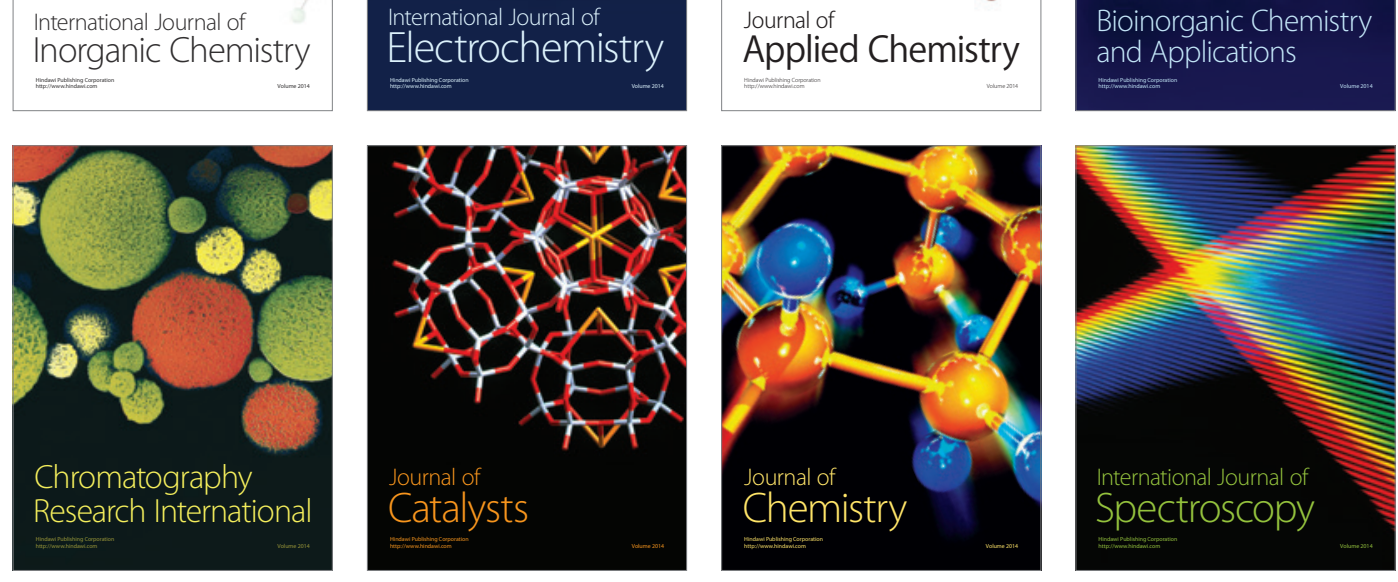